\title{
ANALISIS EFEKTIFITAS CBET (COMPETENCY BASE EDUCATION AND TRAINING) SEBAGAI UPAYA PENINGKATAN SOFT SKILLS, TANGGUNG JAWAB DAN DISIPLIN TERINTEGRASI (STUDI PROGRAM MAGANG MAHASISWA JURUSAN ADMINISTRSI NIAGA POLITEKNIK NEGERI JAKARTA)
}

\author{
Wahyudi Utomo ${ }^{1}$ dan Azwar \\ Jurusan Administrasi Niaga, Politeknik Negeri Jakarta \\ e-mail: ${ }^{1}$ wahyudi.utomo@bisnis.pnj.ac.id
}

\begin{abstract}
This study aims to improve the mastery of student soft skills and discipline through a dual system program and also to find industrial needs about the abilities and skills of students during an internship at the company. This research is descriptive quantitative, using questionnaires and documentation to collect data from respondents. It is expected that the research findings show the effectiveness of the form of dual system learning developed to be able to improve competencies, especially soft skills, responsibilities and discipline of the students.
\end{abstract}

Keywords: competency, internships, soft skills, and effectiveness

\begin{abstract}
Abstrak
Penelitian ini bertujuan untuk meningkatkan penguasaan soft skills tanggung jawab dan disiplin mahasiswa melalui program sistem ganda dan juga menemukan kebutuhan industri tentang kemampuan dan keterampilan mahasiswa selama magang di perusahaan. Penelitian ini bersifat deskriptif kuantitatif, yang menggunakan kuesioner dan dokumentasi untuk mengumpulkan data dari responden.

Diharapkan temuan penelitian menunjukkan efektifitas bentuk pembelajaran sistem ganda yang dikembangkan mampu meningkatkan kompetensi terutama softs skill, tanggung jawab dan disiplin dari para mahasiswa
\end{abstract}

Kata Kunci: kompetensi, magang, softskills, dan efektifitas

\section{PENDAHULUAN}

\section{Latar Belakang}

Magang atau praktek kerja lapangan merupakan salah mata kuliah yang wajib diikuti oleh mahasiswa semester akhir yang sudah menempuh 110 sks di jurusan Administrasi Niaga. Mahasiswa diharuskan memilih sendiri perusahaan yang akan menjadi tempat magangnya. Departemen untuk pelaksanaan disesuaikan dengan konsentrasi yang dipilih, dalam hal ini terbagi menjadi manajemen keuangan, manajemen sumber daya manusia, dan manajemen pemasaran.

Pelaksanaan magang ini bervariasi di setiap perusahaan, dalam arti tidak di semua perusahaan mahasiswa melakukan pekerjaan yang sesuai dengan konsentrasi jurusannya. Prakteknya di lapangan, mahasiswa belum mendapatkan kepercayaan untuk melakukan pekerjaan yang sebenarnya. Oleh karenanya penanaman soft skills merupakan aspek penting dalam menghasilkan lulusan yang mampu bersaing dan berjaya dalam pekerjaannya. Oleh karena itu, diperlukan kajian pola-pola integrasi soft skills dan hard skills dalam pembelajaran dengan berbagai strateginya.

Program magang diharapkan menjembatani antara perguruan tinggi dengan dunia usaha. Namun ternyata apa yang diharapkan tidak berjalan 
sebagaimana mestinya. Mahasiswa magang hanya sekedar lulus mata kuliah namun tidak memiliki arti penting. Pada sisi yang lain, dosen pembimbing tidak terlibat langsung dalam proses magang. Dalam arti mahasiswa magang tidak diberi pengarahan dan bimbingan sebelum dan selama magang. Dosen hanya bertugas mengoreksi laporan yang dikerjakan mahasiswa. Sehingga kegiatan magang sendiri tidak dapat dikontrol dengan baik pelaksanaannya. Sistim pelaksanaan program magang yang sekarang masih belum efektif karena lemahnya koordinasi diantara fihak-fihak yang terlibat, kurang terstruktur, dan kurang selektif, sehingga perlu penyempurnaan.

Berdasarkan hal itulah maka dipandang perlu untuk melakukan penelitian tentang efektifitas program magang yang dilaksanakan oleh jurusan Administrasi Niaga. Sehingga nantinya akan didapat sebuah rekomendasi program magang yang efektif dan sesuai dengan kebutuhan dunia industry. Hal inilah yang menjadi sinkronisasi dunia industry dan dunia pendidikan, atau yang dikenal dengan link and match. Mahasiswa yang melaksanakan magangpun dapat menerapkan konsep yang diperoleh di bangku kuliah

\section{Rumusan Masalah}

Adapun masalah yang akan dirumuskan dalam penelitian ini adalah:

1. Sejauhmana efektifitas program magang dinilai oleh perusahaan dan mahasiswa peserta magang

2. Apakah program magang sebagai implementasi CBET (competency base education and training) dapat meningkatkan kompetensi mahasiswa seperti softskills, tanggung jawab dan disiplin terintegrasi

3. Bagaimana kebutuhan industri tentang kemampuan dan keterampilan mahasiswa selama magang di perusahaan

\section{Tujuan Penelitian}

Berdasarkan rumusan masalah, tujuan penelitian ini yaitu

1. Untuk menguji efektifitas pelaksanaan program pembelajaran sistem ganda yang sudah dilakukan selama ini antara PNJ dan mitra industry atau perusahaan.

2. CBET (competency base education and training) mampu menjelaskan kompetensi hasil belajar mahasiswa yang ditunjukkan oleh kinerja (performansi) secara professional oleh mahasiswa peserta magang seperti soft skills, tanggung jawab, dan disiplin mahasiswa.

3. Dapat menghasilkan suatu bentuk model rancangan program CBET (competency base education and training) dimasa yang akan dating yang mampu memberikan pola pembelajaran terpadu dan efektif berbasis kemitraan dengan industry sehinga program sistem ganda diharapkan dapat menambah tingkat pengetahuan dan kompetensi mahasiswa khususnya softskill mahasiswa Politeknik Jurusan Administrasi Niaga

\section{TinjauAn Pustaka}

Pengertian Magang

Noe, Hollenbeck, Gerhart \& Wright (2003:251) mengemukakan, training is a planned effort to facilitate the learning of job-related knowledge, skills, and behavior by employee. Hal ini berarti bahwa pelatihan merupakan suatu usaha yang terencana untuk memfasilitasi pembelajaran tentang pekerjaan yang berkaitan dengan pengetahuan, keahlian dan perilaku oleh para pegawai.

Menurut Danim dalam Liana Sari, Beti dkk (2014 : 4) yang menyatakan, "magang adalah teknik belajar yang melibatkan pengamatan individual pada pekerjaan dan penentuan umpan balik untuk memperbaiki kinerja atau mengoreksi kesalahan.” Pendapat lain dari Martanto dalam Liana Sari dkk (2014:4), 
mengutip dari Johnson (1992) "Magang adalah metode pelatihan yang terjadi di tempat kerja dan umumnya berupa pelatihan technical skill dan lebih berfokus pada peningkatan produktivitas secara cepat”.

\section{Pengertian Soft Skills}

Secara garis besar soft skill digolongkan dalam dua kategori yaitu kemampuan seseorang dalam mengatur dirinya sendiri (intrapersonal skill) dan kemampuan seseorang dalam berhubungan dengan orang lain (interpersonal skill) yang termasuk dalam interpersonal skill adalah ketrampilan komunikasi, ketrampilan motivasi, ketrampilan kepemimpinan, ketrampilan self marketing, ketrampilan presentasi, kesadaran politik, memanfaatkan keberagaman, orientasi pelayanan, empati, manajemen konflik dan kerjasama tim. Sedangkan intrapersonal skill terdiri dari transformasi karakter, transformasi keyakinan, manajemen perubahan, manajemen stress, manajemen waktu, proses berpikir kreatif, tujuan pengaturan dan tujuan hidup, percaya diri, penilaian sifat, diri dan preferensi, kesadaran emosional, kelayakan dan proaktif. (Widayanty, 2014: 153).

Soft skills adalah kunci menuju hidup yang lebih baik, sahabat lebih banyak, sukses lebih besar, kebahagiaan yang lebih luas, tidak punya nilai, kecuali diterapkan dalam kehidupan sehari-hari baru bernilai. Soft skills yang dimiliki oleh setiap orang dengan jumlah dan kadar yang berbeda-beda yang dipengaruhi oleh kebiasaan berfikir, berkata, bertindak dan bersikap (Aji, 2013: 11).

\section{METODE PENELITIAN}

Jenis penelitian yang digunakan adalah metode penelitian kuantitatif yaitu metode penelitian yang berlandaskan pada filsafat positivisme, digunakan untuk meneliti pada populasi atau sampel tertentu, tehnik pengambilan sampel pada umumnya dilakukan secara random, pengambilan data menggunakan instrumen penelitian, analisis data bersifat kuantitatif/ statistic

\section{Teknik Pengumpulan Data}

Untuk mendapatkan data - data yang diperlukan dalam penelitian ini, digunakan beberapa metode pengumpulan data hinggga mendapatkan sejumlah informasi atau data yang akurat, yaitu:

1) Data dalam penelitian ini menggunakan data kualitatif seperti saran dan masukan yang diberikan oleh pengawas magang dan pengguna.

2) Data kuantitatif menggunakan kuesioner sebagai instrument pengambil data

3) Subjek penelitian ini adalah mahasiswa yang mengambil magang.

Objek penelitian adalah model industri magang yang akan ditinjau berdasarkan: jenis magang, kemampuan mentor dalam pengawasan, dosen hadir, mentor magang Peneliti menggunakan wawancara terstruktur. Wawancara terstruktur ini dilakukan dengan pihakpihak seperti Ketua Jurusan, Kepala program Studi, Kepala Kelompok Bidang Keahlian, Para Dosen pengampu mata kuliah yang berkaitan, dan termasuk mahasiswa.

\section{HASIL DAN PEMBAHASAN}

Pengetahuan mahasiswa mahasiswa dalam bidang ilmu administrasi dan bisnis

Gambar 1. menampilkan persepsi stakeholder terkait dengan mahasiswa dalam bidang ilmu administrasi dan bisnis. Dari Gambar tersebut dapat dilihat bahwa secara umum stakeholder menilai mahasiswa memiliki kemampuan pemahaman bidang ilmu yang baik. 


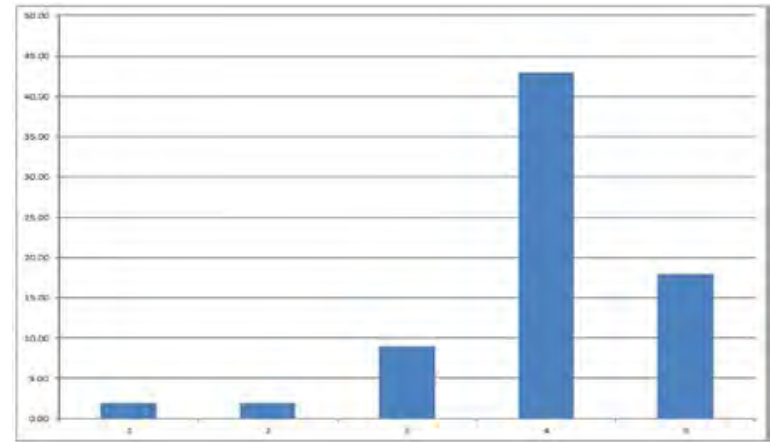

\section{Keterampilan Kerja Mahasiswa}

Gambar 2. menampilkan persepsi stakeholder terkait dengan Keterampilan Kerja Mahasiswa dari mahasiswa dalam lingkungan kerja yang ada saat ini..Dari Gambar tersebut dapat dilihat bahwa secara umum stakeholder menilai mahasiswa mempunyai keterampilan yang baik dalam pekerjaan yang diberikan dan menjadi tanggung jawabnya.

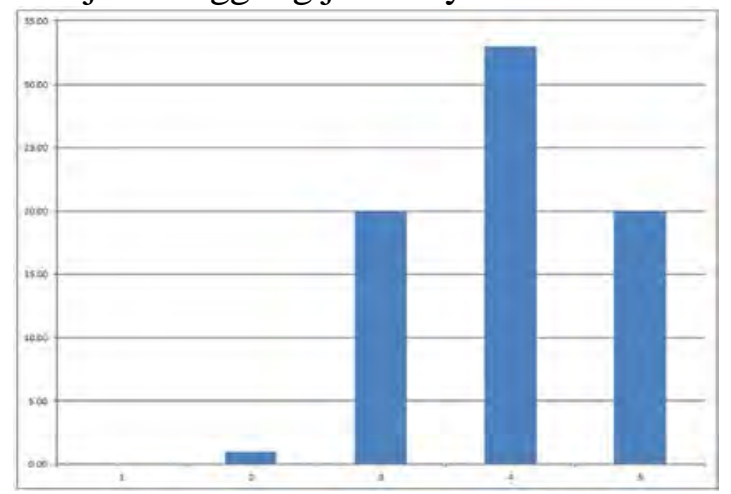

\section{Kemampuan Berbahasa Asing}

Gambar 3. menampilkan persepsi stakeholder terkait dengan kemampuan mahasiswa dalam berkomunikasi dalam bahasa asing. Dari Gambar tersebut dapat dilihat bahwa secara umum stakeholder menilai mahasiswa mempunyai kemampuan berbasa asing yang cukup baik

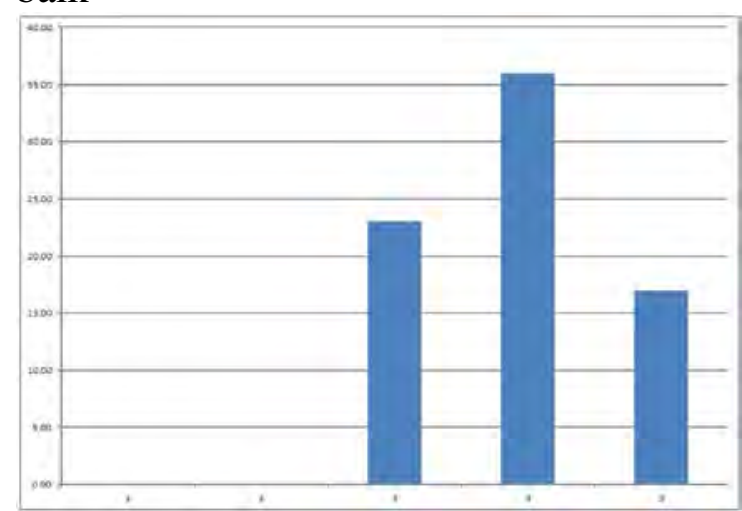

Namun dengan mempertimbangkan bahwa cukup besar stakeholder yang memberikan penilaian 3 terhadap aspek ini, menunjukkan perlunya adanya konfirmasi terkait kebutuhan bahasa asing apa saja yang menjadi opsi tambahan yang dibutuhkan oleh industri.

\section{Etika Kerja \& Profesi mahasiswa di tempat kerja}

Gambar 4. menampilkan persepsi stakeholder terkait Etika Kerja \& Profesi mahasiswa di tempat kerja. Dari Gambar tersebut dapat dilihat bahwa secara umum stakeholder menilai mahasiswa memiliki Etika Kerja \& Profesi mahasiswa di tempat kerja yang baik.

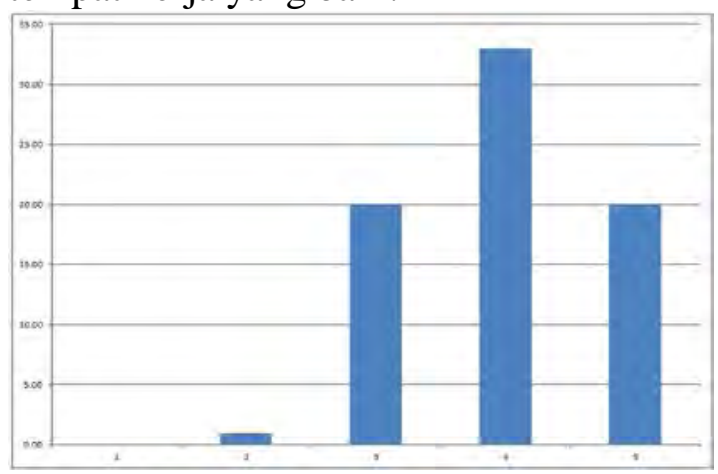

\section{Kemampuan bekerja dalam tim}

Gambar 5. Menampilkan persepsi stakeholder terkait dengan kemampuan mahasiswa bekerja dalam tim.

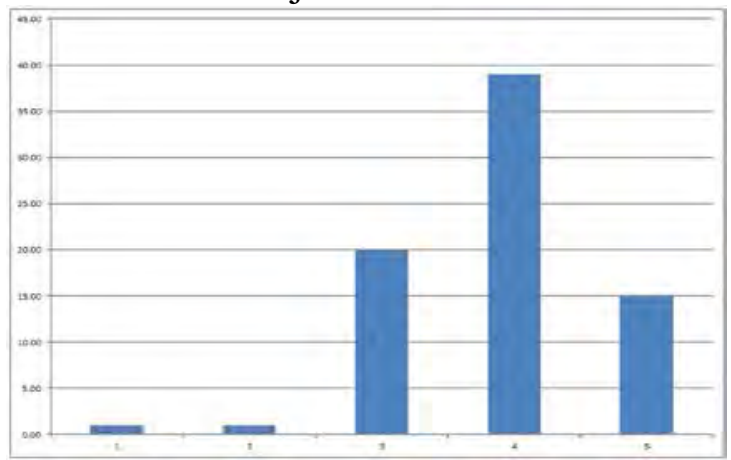

Dari Gambar tersebut dapat dilihat bahwa secara umum stakeholder menilai mahasiswa mempunyai kemampuan bekerja yang baik dalam tim. Hasil survey menunjukkan bahwa stakeholder puas terhadap mahasiswa 


\section{KESIMPULAN DAN SARAN}

\section{Kesimpulan}

Berdasarkan hasil penelitian dapat disimpulkan sebagai berikut :

1. Sebagian besar mahasiswa Program Studi Administrasi Bisnis telah mampu memenuhi kebutuhan stakeholder.

2. Ada beberapa mahasiswa yang masih belum memenuhi kebutuhan stakeholder

\section{Saran}

Sesuai dengan hasil kesimpulan maka disarankan perlu mengidentifikasi beberapa kelemahan yang ada pada beberapa mahasiswa.

\section{DAFTAR PUSTAKA}

Agus,Suprijono.2009. Cooperative learning Teori dan Aplikasi Paikem.Yogyakarta:

Pustaka Pelajar

Bowden, J. \& Masters, G. 1993. Implicationsfor Higher Education of A Competency-Based Approach to Education and Learn-ing. Canbera: AGPS. Prentice-Hall, Inc.

Dyah Setyorini, dkk. Model Magang Industri Guna Pencapaian Standar Kompetensi Lulusan FE Universitas Negeri Yogyakarta. Jurnal Pendidikan Akuntansi Indonesia, Vol. XIV, No. 2, Tahun 2016

Edi Suswardji, dkk. Hubungan Kompetensi dan Disiplin Kerja Terhadap Kinerja Tenaga Kependidikan Universitas Singaperbangsa Karawang . Jurnal Manajemen Vol.10 No.1 Oktober 2012.

Golemen, Daniel. "Working With Emotional Intelegence: Kecerdasan Emosional Untuk Mencapai Puncak Prestasi”. Jakarta: PT. Gramedia Pustaka Utama. 2000.
Hamida."Peningkatan Soft skills Tanggung Jawab dan Disiplin Terintegrasi Melalui Pembelajaran Praktik Patiseri”. Jurnal Pendidikan Karakter, Universitas Negri Yogyakarta Vol.1 No.2, Juni 2012

Joyce, Bruce \& Weil, Marsha. 2009. Model of Teaching. Boston:Allynand Bacon Publisher.

Liana Sari, Beti dkk. Studi Kepuasan Pengguna Magang Mahasiswa Pendidikan Ekonomi BKK Pendidikan Administrasi Perkantoran. FKIP UNS 2014. Jurnal.fkip.uns.ac.id. diakses tanggal 10 April 2018

Lilik,Salmah dkk. Tingkat Penguasaan Self Regulated learning Skills Ditinjau Dari Segi Prestasi Belajar dan Lama Studi Pada Mahasiswa FKIP UNS

Masitoh dan Laksmi Dewi, 2009, Strategi Pembelajaran, Jakarta: Direktorat Jenderal Pendidikan Islam Depag RI

Muslih. Analisis Efektifitas Program Magang Untuk Sinkronisasi link and match Perguruan Tinggi Dengan Dunia Industri. Jurnal Manajemen \& Bisnis Vol 14 no. 01 April 2014

Nitta."Pengaruh Pendidikan Dan Pelatihan Terhadap Peningkatan Kinerja Karyawan Pada Balai Pelatihan Teknis Pertanian Kalasey”. Jurnal EMBA Fakultas Ekonomi, Universitas Sam Ratulangi Manado. ISSN 2303-1174 Vol.1 No.3 Juni 2013.

Noe, Hollenbeck, Gerhart, Wright, 2003, Human Resource Management, International Edition, The McGrawhill Companies, Inc. New York

Parsaoran, S. dan Liliasari. 2010.Model Pembelajaran untuk MeningkatkanKemampuan Calon Guru Sekolah Dasar dalam Pendekatan Pembelajaran dan Asesmen 
Preston, B.\& Walker, J. 1993. Competency Standards in the Professions and Higher Education: a Holistic Approach. Canber-ra: Australian College of Education,

Prihadi, Syaiful F. 2004. Assesment Centre,Identifikasi, Pengukuran, dan Pengembangan Kompetensi. Jakarta: PT. Gramedia Pustaka Utama.

Kessler, Robin. 2011. Competency Based Performance Reviews. Jakarta: PM

Purnami."Implementasi Metode Experiental Learning Dalam Pengembangan Softskill Mahasiswa Yang Menunjang Integrasi Teknologi, Manajemen dan Bisnis”. Jurnal Penelitian Pendidikan , Magister Manajemen Bisnis, Sekolah Pascasarjana, Universitas Pendidikan Indonesia. ISSN 1412565 X Vol. 14 No. 1, April 2013.

R. Mursid, 2011. Pengembangan Model Pembelajaran Praktik Berbasis Kompetensi Berorientasi Produksi

Rivai, Veithzal dan Ahmad Fawzi Mohd Basri. $2005 . \quad$ Performance Appraisal. Jakarta: Raja Grafindo Persada

2003. Kepemimpinan dan Perilaku Organisasi. Jakarta: Raja Grafindo Persada

Setyantoko Nur Aji. “Kemampuan Soft Skill Guru Pendidikan Jasmani Olahraga Dan Kesehatan SMA Negri Se-Kabupaten Purwerejo". Fakultas Ilmu Keolahragaan, Universitas Negeri Yogyakarta, Skripsi: 2013.

Siti Halimah, 2012. Penerapan Studi Pembelajaran Aktif di Pendidikan Guru Madrasah Ibtidaiyah

Siti Hamidah dan Sri Palupi. Peningkatan Soft Skills Tanggung Jawan dan Disiiplin melalui Pemebelajaran Patiseri. Jurnal Pendidikan Karakter, Tahun II, Nomor 2, Juni 2012
Wagiran, Sudji Munadi, Syukri Fathudin

AW. Pengembangan Model

Penguatan Soft Skills Dalam

Mewujudkan Calon Guru

Profesional Berkarakter. Jurnal

Kependidikan, Volume 44, nomor 1, mei 2014, halaman $92-102$.

Wibowo. 2010. Manajemen Kinerja. Jakarta: Raja Grafindo Persada - 2010. Budaya Organisasi. Jakarta: Raja Grafindo Persada

Widayanti."Pengaruh Hard Skill dan Soft Skill Terhadap Kinerja Karyawan (Studi pada PT. Telkom Kandatel Malang)”. Jurnal Dinamika Dotcom, STMIK Pradnya Paramita Malang Vol 3. No. 1 : 2014.

Yanti."Pengaruh Kompensasi, Motivasi Kerja, Lingkungan kerja dan disiplin terhadap Kinerja Karyawan pada CV Koperasi Puri Kencana Taxi Semarang”. Jurnal Ekonomi, Jurusan Managemen, Fakultas Ekonomi, Universitas Pandanaran. Semarang : 2010. 